\title{
Public Behavior and Attitude Towards Government Policies During the Pandemic of COVID-19 in Indonesia
}

\author{
Erisva Hakiki Purwaningsih ${ }^{1 *}$, Qur'ani Dewi Kusumawardani ${ }^{1}$, Marudur \\ Pandapotan Damanik ${ }^{1}$
}

\author{
${ }^{I}$ The Agency for Research and Human Resource Development, Ministry of Communication and Informatics \\ Republic of Indonesia \\ *Corresponding author. Email: eris001@kominfo.go.id
}

\begin{abstract}
The COVID-19 pandemic has affected global social life. By far, cases of COVID-19 transmission in Indonesia have not shown a significant decrease. Preventing the spread of COVID-19 outbreak requires society awareness to consistently implement health protocols and comply with government policies. This study aims to describe public behavior in implementing a healthy life and how public attitude complies with government policies related to COVID-19. This research is a quantitative descriptive study conducted by collecting data through online survey and literature studies. The survey was conducted with a non-probability sampling design that combines convenience and snowball techniques for 11 days and obtained 911 respondents from all regions of Indonesia. The result shows that respondents had raised awareness toward the importance of implementing health protocols during a pandemic. The respondents also generally agree with the policies taken by the government in preventing the spread of COVID-19., such as stopping public transportation, closing houses of worship, and so on. However, respondents do not agree with the policy of ceasing market activities. The findings was confirmed because the respondents has good information literacy since they are internet users. This is consistent with other studies which suggest that people with low levels of information literacy tend to neglect the implementation of health protocols. This study emphasizes the importance of disseminating information by media related to the pandemic and equitable internet access so that all people can get adequate information.
\end{abstract}

Keywords: COVID-19 pandemic, society awareness, government policy.

\section{INTRODUCTION}

The COVID-19 pandemic that has been spreading since December 2019 in Wuhan is still becoming a global concern. The virus has spread to more than 216 countries worldwide. COVID-19 is a disease that changes social behavior, social cohesion, and social structures in society [1]. Every country should be implementing a comprehensive set of measures, calibrated to their capacity and context, to slow down transmission and reduce mortality associated with the COVID-19, ultimately to reach and/or maintain a steady state of low-level or no transmission.

internet access to obtain a variety of information. People with all types of cellular phones can take
Public awareness in dealing with the COVID-19 pandemic has become very important by providing education to the wider community regarding dangers and how to prevent them, especially in government. To raise public awareness, the government of Indonesia provides Interactive Voice Response (IVR) 321 services as a media for COVID-19 prevention education. The service was initiated by the Ministry of Health, USAID, and PT XL Axiata Tbk. Service 321 is also an option for communication channels that can be accessed by the general public to obtain information about COVID19. Telephone service 321 provides an opportunity for more Indonesians who have limitations in

advantage of this service to get information quickly about COVID-19 and various other useful 
information to improve health and well-being. Not all customers and people use smartphones with access to the internet. Some of them are still using regular telephones, including those who live in areas where the internet is not sufficiently covered [2].

Apart from using Interactive Voice Response, the Indonesian government through various ministries and institutions also disseminates information related to COVID-19 and its dangers in various media channels, such as social media, television, broadcast SMS, WhatsApp, posters/billboards, community leaders, houses of worship and via radio channels. This is in line with the results of the latest BPS survey which showed that the public has used various media to obtain information on health protocols and the importance of preventing the spread of COVID-19. Social media, television, and Whatsapp are also categorized as the most popular media for the community in obtaining information about health protocols and prevention of the spread of COVID-19. as can be seen in Figure 1 below.

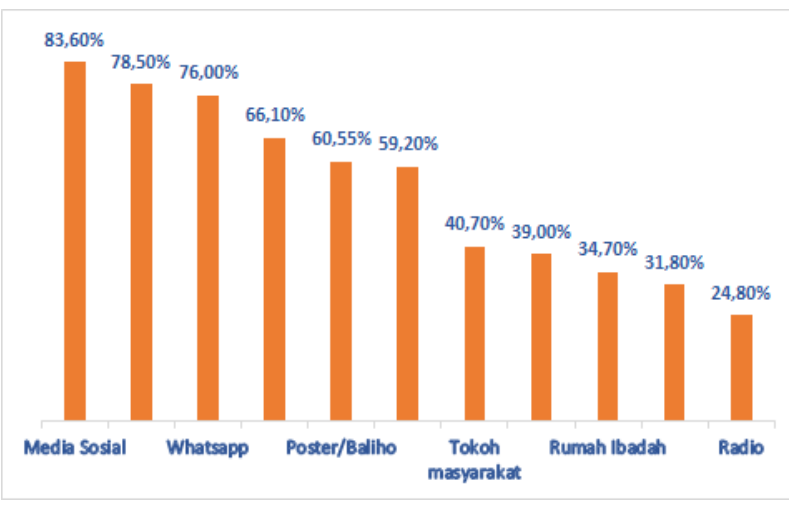

Source: BPS, 2020

Figure 1. Media used by people in obtaining information about COVID-19

The lack of a correct understanding of the transmission of COVID-19 and the lack of risk communication cause the public to not be disciplined in implementing health protocols. Community compliance is becoming increasingly important. Efforts to build public awareness must be increased in various ways, one of which is with the help of technology. China and Western democracies including the United States of America (USA), the United Kingdom (UK), Italy, Germany, Belgium, the Netherlands, France, and Spain are known for adopting smart technologies such as the Internet of things (IoT), big data, and artificial intelligence (AI) [3]. Indonesia is no exception, which also uses technology.
Technology is one of the necessary tools to help people adapt. The rapid development of technology like artificial intelligence (AI), the internet of things (IoT), and big data will help us to automate some processes without any human intervention. These technologies can empower other existing technology like CCTV, public address systems, and even our mobile phones. Indonesia Presidential Regulation No $39 / 2019$ on data provides a strong base to stimulate big data utilization in social aid data distribution, despite the challenges in a crisis. Big data can play a major role in adapting with a postpandemic period, especially in formulating better decisions for the future [4].

As shown in Figure 2, the trend on COVID-19 daily cases in Indonesia has not shown a significant decline, even though the government has issued a policy to control the spread of the disease, including:

1) Government Regulation Number 21 of 2020 concerning Large-Scale Social Restrictions in the context of the Acceleration of Handling Corona Virus Disease 2019 (COVID-19) was set on March 31, 2020. Local Governments can implement Large-Scale Social Restrictions (PSBB) for one province or district or specific city. The PSBB is carried out by proposing by the governor/regent/mayor to the Minister of Health.

2) Minister of Health Regulation No. 9 of 2020 concerning PSBB Guidelines for the Accelerated Handling of COVID-19 was set on April 3, 2020. PSBB policies include: limitation on school and workplace activities, restriction of religious activities, restrictions on activities in public places/facilities, limitation of sociocultural activities, restrictions on transportation modes, and restrictions on other activities related to defense and security aspects;

3) On April 7, 2020, the Minister of Health approved the PSBB to be implemented in DKI Jakarta. During the enforcement of PSBB for 14 days, online motorcycle taxis are prohibited from carrying passengers, and the commuterline schedule was re-evaluated and reduced.

Certainly, this policy must be followed by people's healthy behavior and public compliance so that the number of new cases does not increase. Therefore, in the present study, we want to investigate people's behavior amid increasing cases and the level of public compliance with government policies, especially after the implementation of various policies related to COVID-19 such as Large- 
Scale Social Restrictions, the closing of places of worship and public spaces.

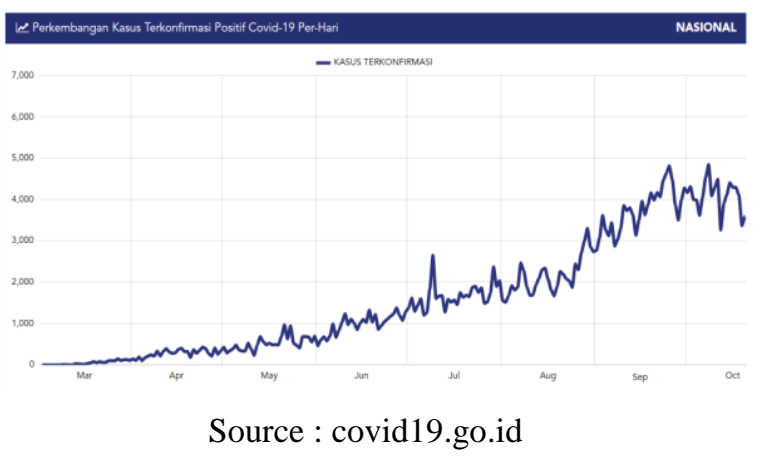

Figure 2. Trends on COVID-19 daily case

\section{RESEARCH METHOD}

This research was conducted as a descriptive quantitative study that analyzes both primary and secondary data. The primary data were collected through an online survey while the secondary data consists of literature and paper related to the problems that persisted in this research. The survey was conducted with a non-probability sampling design that combines convenience and snowball techniques for 11 days from May $4^{\text {th }}$ to $15^{\text {th }} 2020$, and obtained 911 respondents from all regions of Indonesia.

\section{FINDINGS AND DISCUSSION}

\subsection{Socio-demographic profile of respondents}

The online survey managed to get 911 responses, with a composition of $46 \%$ aged $31-39$ years old, $22 \%$ for $25-30,18 \%$ aged $40-50,8 \%$ aged $17-24$, and $6 \%$ aged over 50 . Based on their education, $57 \%$ of them are undergraduates and $20 \%$ respectively are from high school and master's education, while the rest are primary and junior high school graduates. To describe the distribution of the survey area, most of the respondents are from Java and Sumatera. Based on their work status, $62 \%$ are employees, $30 \%$ are entrepreneurs or freelancers, while the other $8 \%$ are workers who have been dismissed or suspended.
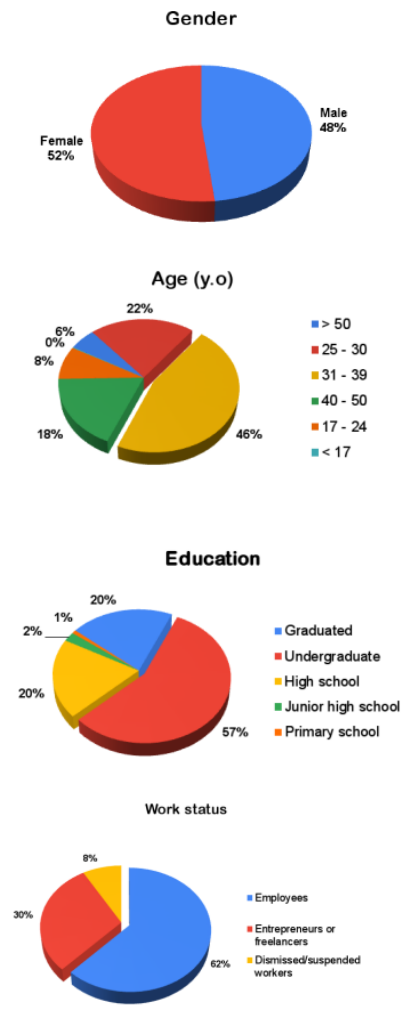

Figure 3. Socio-demographic profile of respondents

\subsection{People's behavior in preventing COVID- 19 outbreak}

To prevent the spread of COVID-19, people are required to adopt healthy living habits. Implementing health protocols consistently as recommended by the government is the key to controlling the transmission. This study shows that during the COVID-19 pandemic, people have shown their concern for healthy living and tend to keep themselves and their families from being infected by the disease. The figure below shows people's efforts to prevent the spread of COVID-19 by using masks (94.7\%), washing hands $(93.7 \%)$, physical distancing $(91.3 \%)$, staying at home $(91.8 \%)$, and compliance with the government's instruction on social restriction $(91.8 \%)$. This has become a new positive habit for society. However, their behavior in using disinfectants on their property is not up to the expected standard. Furthermore, their social activity during the pandemic is also quite low. 


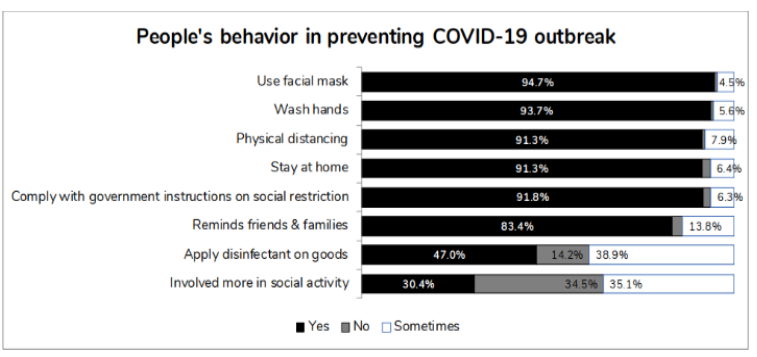

Figure 4. People's behavior in preventing COVID19 outbreak

This result is in line with the study on the impact of COVID-19 conducted by BPS, which states that the public has already known the recommendation of physical distancing and has followed this policy including washing hands and using masks. Respondents who did not adopt new habits in dealing with COVID-19 argued that there were no penalties for not complying with health protocols, while the other reason was that they thought that there were no cases of COVID-19 in their surroundings [5]

Another research finding shows that during the pandemic, people have restricted themselves from leaving their homes when they don't have urgent interests. This behavior was even carried out by respondents who dismissed/suspended workers (Figure 2), although looking for a new job makes it possible for them to be outside the home so that their family needs are met. This shows that the respondents are very concerned about personal and family health.

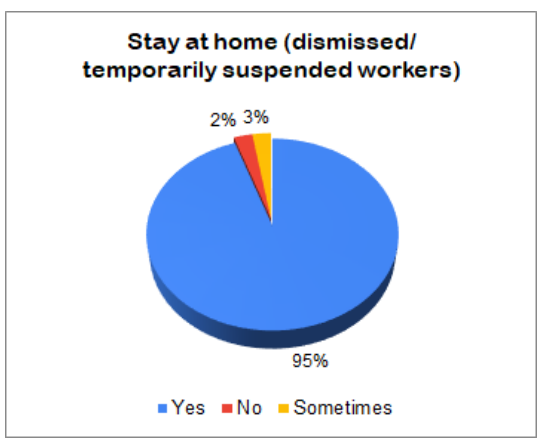

Figure 5. Stay at home by respondents who dismissed/suspended workers

\subsection{Attitudes toward government instructions regarding COVID-19}

During the pandemic, the government has released several policies to stop the spread of COVID-19 even though the implementation was not evenly distributed throughout Indonesia. These policies include stopping the operation of public transportation links, restricting access on regional borders, closing stores on the markets, prohibiting dine-in on cafes and restaurants, prohibiting homecoming activity, limiting religious activities in house of worship, prohibiting activities that gather large numbers of people, and implementing largescale social restrictions (PSBB).

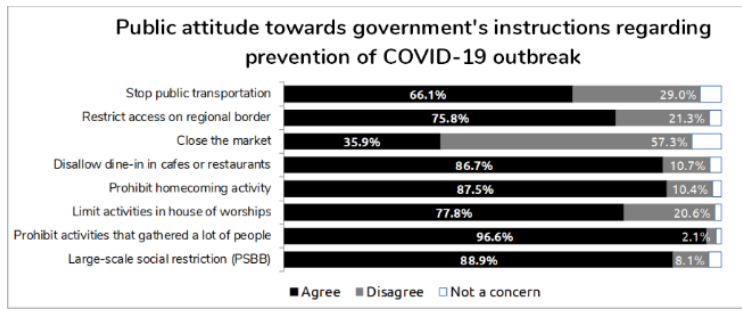

Figure 6. Public attitude towards government's policy regarding COVID-19

The study reveals that respondents generally agree with the policies taken by the government, except for closing shops in the market. This situation is understood because the market is a place of economic activity. This evidence becomes interesting because the culture of Indonesian is often seen as a religious society, yet the public prefers to close houses of worship rather than the markets. It is well-known that the market is one of the public spaces that have a high potential for COVID-19 transmission as it is a gathering place for a lot of people. These findings can be seen in Figure 6.

As seen in Figure 7, respondents who disagree with "market closure" policy are not only female respondents, who in this case are mothers and entrepreneurs/freelancers who carry out activities in the market to meet their daily needs, but also from male respondents and respondents who work as employees. Although basic needs and other necessities are available in online marketplaces, traditional markets are still the main choice for people to shop for their daily needs, so the availability of commodities and public safety while shopping at the market are important things that must be met to prevent the spread of COVID-19. 

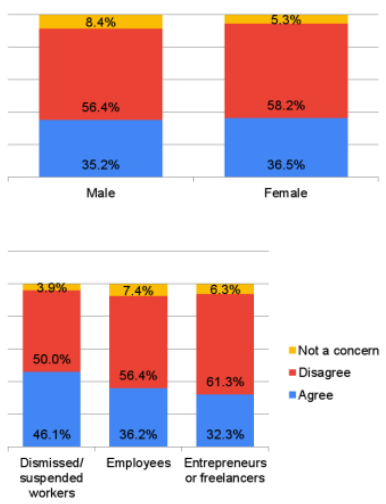

Figure 7. Public attitude on closing the market (based on gender and work status)

Overall, the survey findings suggest that people have a new perspective on the importance of staying healthy. People become more active at home, such as working, studying, worshiping, and socializing by means of technology.

Based on an interim report from 285 local governments during the pandemic, the number of traders in traditional markets has decreased by an average of $29 \%$. The decline also occurred in sales of an average of $39 \%$ which was caused by lack of buyers. Retail business players also experienced a similar situation, whose turnover fell by $90 \%$ and supply of goods decreased by $50 \%$. This condition could have a broader impact where traders would experience a decrease in their ability to complete their obligations, such as paying taxes, rent, electricity and gas, loan installments, and paying employee salaries. In general, COVID-19 has an impact on the trade sector, both decreasing purchasing ability and weakening trade transactions in public markets and modern retail [6].

For this reason, The Minister of Trade asked traditional markets to continue operating by maintaining market cleanliness, and consistently implementing physical distancing in optimizing the implementation of Large-Scale Social Restrictions (PSBB) in several regions. The Ministry of Trade will cooperate with the Ministry of Home Affairs, the national agency for disaster management, and the Regional Task Force, local governments, and related organizations in monitoring traditional markets to keep them clean and hygienic [6].

\subsection{The role of media and internet access towards information acceptance}

The intensive socialization of information regarding the importance of complying with health protocols to prevent the transmission of COVID-19 is one of the factors so that people follow these rules. Communication media has a significant influence on changes in culture and behavior, both in the mindset and lifestyle of the community [7]. The growth of mass media allows information to spread easily to the public. Information in any form can be disseminated easily and quickly so that it affects the outlook, lifestyle, and culture of a nation [8]. According to Cahyono, the dissemination of information through social media can take place very quickly because it can be spread and received anytime and anywhere. The presence of social media creates changes in obtaining information to be more effective and efficient [9].

Furthermore, the intellectual society with sufficient information literacy has a similar response to the above. Nastain and Rochwidowati stated that people with low levels of education and low literacy skills tend to ignore this pandemic. People who generally live in rural areas with a communal system sometimes have resistance to government health protocols on the pretext of habit (culture) or religious reasons [10]. This statement was also confirmed by other studies, stating that the higher the level of education, the more they convinced that COVID-19 is contagious and dangerous [5]. Knowledge, attitudes, and behavior of a person are very much determined by the level of education and will also affect the ability to receive information [11].

In this study, we also confirmed those statements above given that most of the respondents gave positive responses in implementing health protocols and complying with government regulations. This can be explained because the respondents are internet users who certainly have good information literacy. Thus it can be concluded that the level of internet literacy and public information literacy is related to awareness and compliance to implement health protocols. Therefore, the government has an important role in providing internet access for the community. It is hoped that with equitable internet access, all people can acquire the same information so that they can raise awareness in implementing new habit adaptations and following government policies to prevent the spread of COVID-19.

\section{CONCLUSION}

The results of this study indicate that the majority of respondents have adopted new habits and followed government policies related to COVID-19, although they tend to be reluctant to stop market activity. This is because the respondents are those 
who are well literate with the internet and have received sufficient information about COVID-19. This study also found that the COVID-19 pandemic forces people to use technology in various activities. This situation accelerates digital transformation. Digital transformation is one of the focuses of Indonesian government policies that have been compiled to be implemented until 2024. Further research related to public awareness is needed in rural areas to obtain further empirical findings with the consideration that rural areas have limited access to information, especially on internet access. Equitable internet access policies are still needed in rural areas, especially during the COVID-19 pandemic.

Furthermore, the government also needs to monitor, evaluate and further explore the impact of COVID-19 in a more comprehensive manner, such as in the economic aspect or reducing the number of unemployment to avoid a bigger social crisis.

\section{AUTHORS' CONTRIBUTIONS}

All the authors contributed equally to this work.

\section{ACKNOWLEDGMENTS}

We would like to thank our colleagues at The Agency for Research and Human Resource Development, Ministry of Communication and Informatics Republic of Indonesia.

\section{REFERENCES}

[1] Syaifudin, "Negara, Masyarakat dan Era New Normal," tempo.co, 2020. https://kolom.tempo.co/read/1351996/negaramasyarakat-dan-era-new-normal (accessed Oct. 07, 2020).

[2] Kemenkes, "Kampanye Perubahan Perilaku, Pemerintah Sediakan Layanan Informasi COVID-19 di Nomor 321," 2020. https://www.kemkes.go.id/article/print/20052 000003/kampanye-perubahan-perilakupemerintah-sediakan-layanan-informasiCOVID-19-di-nomor-321.html (accessed Oct. 19, 2020).

[3] R. K. R. Kummitha, "Smart technologies for fighting pandemics: The techno- and humandriven approaches in controlling the virus transmission," Gov. Inf. Q., vol. 37, no. 3, p. 101481, Jul. 2020, doi: 10.1016/j.giq.2020.101481.
[4] A. M. Dermawan, "Brave New Technology for Post-Pandemic Society." https://www.thejakartapost.com/Life/2020/07/ 22/Brave-New-Technology-For-PostPandemic-Society.html (accessed Oct. 01, 2020).

[5] BPS, Hasil Survei Sosial Demografi Dampak COVID-19. Jakarta: Badan Pusat Statistik, 2020.

[6] Kemdag, "Lawan COVID-19: Mendag Minta Pasar Rakyat Tetap Harus Beroperasi Agar Ekonomi Masyarakat Kecil Berjalan,” 2020. https://www.kemendag.go.id/storage/article_u ploads/4CZR7U6RzUCScLJRDzmZIDdnToF 4wf3nrw1s9UYE.pdf (accessed Oct. 19, 2020).

[7] I. Setyawati, "Peran Komunikasi Massa dalam Perubahan Budaya dan Perilaku Masyarakat," Fokus Ekon., vol. 2, no. 3, 2008.

[8] S. A. Hamid, "Pengaruh media massa terhadap perubahan sosial masyarakat," e-BANGI, vol. 11, pp. 214-226, 2016.

[9] A. S. Cahyono, "Pengaruh media sosial terhadap perubahan sosial masyarakat di Indonesia," J. Publiciana, vol. 9, no. 1, pp. 140-157, 2016.

[10] N. S. Rochwidowati and M. Nastain, "Tantangan masyarakat komunal dalam menghadapi pandemi COVID-19," in COVID19 Dalam Ragam Tinjauan Perspektif, D. H. Santoso and A. Santosa, Eds. Yogyakarta: MBridge Press, 2020, pp. 403-410.

[11] Sriyono, "Pengaruh Tingkat Pendidikan dan Pemahaman Masyarakat tentang Ikan Berformalin terhadap Kesehatan Masyarakat," Fakt. Exacta, vol. 8, no. 8, pp. 79-91, 2015. 